\title{
Mendapatkan Peringkat Terbaik Website Pada Search Engine Dengan Metode Search Engine Optimization (SEO)
}

\author{
Sukri Sukri $^{{ }^{*}}$, Zulfikar Zulfikar $^{2}$ \\ ${ }^{1,2}$ Univbersitas Abdurrab Pekanbaru \\ J1. Riau Ujung No. 73 Pekanbaru \\ Corresponding author‘s e-mail: sukri@univrab.ac.id
}

\begin{abstract}
Abstrak-Sekarang ini merupakan era internet dimana semua orang mampu melakukan apa saja melalui internet salah satunya adalah dengan menggunakan internet sebagai lahan promosi bisnis. Agar bisa berpromosi di internet maka diperlukan website sebagai sumber informasi yang memberi manfaat bagi pengunjung. Agar stategi promosi dapat berhasil dengan baik, maka seharusnya website muncul dihalaman pertama search engine yang harus dilakukan adalah upaya optimasi off page dan optimasi artikel. Optimasi website bukanlah suatu hal yang mudah, untuk mendapatkan hasil yang baik maka diperlukan beberapa optimasi search engine yang baik dan benar. Dengan adanya metode SEO, maka akan mempermudah pemilik website melakukan optimasi. Hasil dari optimasi SEO adalah website akan mendapatkan peringkat terbaik di search engine.

Kata Kunci: internet, website, search engine, Search Engine Optimization (SEO).
\end{abstract}

ABSTRACT-Now this is the internet era where everyone is able to do anything through the internet one is to use the internet as a land of business promotion. In order to promote on the internet then needed a website as a source of information to the benefit of visitors. Promotional strategies in order to work well, then the website should appear first page of search engines to do is attempt optimization and off page optimization articles. Optimization of a website is not an easy thing, to get good results then needed some search engine optimization is good and right. With the SEO methods, it will be easier to optimize the website owner. Results of SEO optimization is the best website will get ranked in the search engines.

Keywords: internet, website, search engine, Search Engine Optimization (SEO).

\section{Pendahuluan}

Kemajuan dan tingginya perkembangan teknologi informasi telah mendorong munculnya berbagai jenis website sebagai penyedia informasi. Pada saat ini sudah banyak sekali jumlah website yang sudah ada di internet. Suksesnya website biasanya sebagian besar ditentukan oleh trafik, jadi trafik adalah hal penting yang perlu dipikirkan oleh pemilik website. Sepinya pengunjung tentunya merugikan bagi mereka yang menjadikan website sebagai lahan bisnis di internet.

Menurut riset Asosiasi Penyelenggara Jasa Internet Indonesia (APJII) mengungkapkan jumlah pengguna internet di Indonesia tahun 2014 adalah 88,1 jutajiwa, 68,7\% pengguna internet itu melakukan aktivitasnya untuk mencari informasi [1]. Tentunya ini menjadi peluang besar agar website yang telah dibuat dapat didatangi pengunjung yang banyak. Berdasarkan survei yang dilakukan oleh Asosiasi Penyelenggara Jasa Internet Indonesia APJII tahun 2017, terdapat sebanyak 75,5\% dari penduduk Indonesia yang berumur 13-18 tahun merupakan pengguna internet aktif[2].

Agar website dapat mudah dikenali pada mesin pencari data dan muncul di halaman awal pada pencarian, maka solusi yang ditawarkan adalah dengan menerapkan metode SEO. Metode SEO pernah diterapkan dan diuji tingkat keefektifitasannya pada salah satu situs penjualan online UKM di Indonesia [3].

Salah satu proses yang membutuhkan SEO Untuk meningkatkan penjualan, pengusaha kuliner memanfaatkan media sosial sebagai strategi pemasarannya memilih melalui internet dengan memanfaatakan media sosial, update informasi, respon terhadap pembeli, kualitas dan harga. Hal ini menggambarkan SEO dapat dimanfaatkan untuk menaikkan reting produk UMKM [4].

Banyak sumber yang dapat mendatangkan trafik ke website, salah satunya melalui seacrh engine. Para pencari informasi biasanya mengetikkan kata kunci yang mereka cari melalui search engine. Maka untuk berpeluang besar mendatangkan trafik, website seharusnya terindeks dengan baik oleh search engine sehingga berpeluang besar muncul di halaman pertama ataupun kedua dari Search Engine Result Page (SERP). Maka dari itu, agar website yang dibuat bisa dengan mudah ditemukan lewat search engine, maka perlu diterapkan metode Search Engine Optimization (SEO)[5]. 


\section{Tinjauan Pustaka}

\subsection{Internet}

Internet atau interconnected networking merupakan sistem global dari seluruh jaringan komputer yang saling terhubung satu sama lain dengan menggunakan standar protokol komunikasi Transmission Control Protocol/Internet Protocol (TCP/IP)[6]. Sehingga setiap pemakai yang komputernya terhubung ke internet dapat saling mengakses layanan yang disediakan oleh komputer lain, dalam bentuk pertukaran data, gambar, video, dan suara yang dapat dilakukan secara langsung menurut.

\subsection{Web}

World wide web (WWW) atau web adalah salah satu dari sekian banyak layanan yang ada di Internet. Layanan ini paling banyak digunakan di Internet untuk menyampaikan informasi karena sifatnya mendukung multimedia [7]. Artinya informasi tidak hanya disampaikan melalui teks, tapi juga gambar, video dan suara. Secara terminologi, website adalah kumpulan dari halaman-halaman situs, yang biasanya terangkum dalam sebuah domain atau subdomain, yang tempatnya berada di dalam world wide web di Internet[8].

Homepage adalah halaman awal dari sebuah website berisi informasi dalam bentuk teks, gambar, maupun format tertentu yang sudah ditetapkan oleh pemilik website. Homepage bisa juga berisi simpul halaman ataupun daftar isi dari halaman website. Setiap calon pengunjung bisa mengakses website secara langsung maupun tidak langsung. Untuk akses yang secara langsung ini biasanya pengunjung akan diarahkan ke halaman homepage. Sedangkan akses tidak langsung misalkan melalui search engine maka pengunjung tersebut akan menuju ke halaman kedua yang berisi kata kunci yang diisi melalui search engine. Homepage adalah halaman situs web yang otomatis ditampilkan saat pertama membuka browser. Tentunya ini akan menghemat waktu apabila sering mengakses situs web tertentu.

Hypertext Transfer Protocol (HTTP) merupakan protokol yang digunakan dalam web yang didefinisikan dalam beberapa Request For Comments, HTTP telah mengalami beberapa perbaikan dari versi pertamanya HTTP 0.9 sampai 1.1 yang merupakan beberapa versi terbaru. HTTP merupakan protokol pada lapisan aplikasi yang digunakan untuk mendistribusikan dan mengkolaborasikan sistem informasi hipermedia. HTTP memungkinkan dokumen HTML dilihat melalui aplikasi web browser dengan memberikan permintaan kepada web server melalui alamat atau URL yang sesuai[9].

Web server adalah komputer yang digunakan untuk menyimpan dokumen-dokumen web, komputer ini akan melayani permintaan dokumen web dari kliennya[10]. Web browser seperti explorer atau navigator berkomunikasi melalui jaringan (termasuk jaringan internet) dengan web server, menggunakan HTTP. Browser akan mengirimkan request ke server untuk meminta dokumen tertentu dan layanan yang disediakan oleh server. Contoh web server seperti Apache, IIS (Internet Information Services), dan PWS (Personal Web Server).

\subsection{Search Engine}

Search Engine adalah sebuah website yang di desain untuk mencari berbagai sumber informasi yang ada di dalam layanan World Wide Web (WWW), file transfer protocol (FTP), Mailing List. Hasil dari pencarian akan menampilkan banyak data informasi yang berasal dari website penyedia informasi.

Search engine adalah situs khusus di internet yang dirancang untuk membantu para netter untuk menemukan informasi yang tersimpan di halaman situs lain. Ada perbedaan cara kerja dari berbagai macam search engine yang tersedia di internet, tetapi pada dasarnya ada tiga hal utama yang dilakukan oleh setiap search engine, yaitu: Search engine menjelajah internet atau memindai bagian internet berdasarkan pada katakata penting [10]. Search engine mencatat indeks kata-kata yang ditemukan dan dimana ditemukannya Search engine yang memungkinkan pengguna untuk mencari kata-kata atau kombinasi kata-kata yang ditemukan dalam pengindeksan tersebut.

\subsection{Search Engine Optimization}

Search Engine Optimization (SEO) adalah sebuah upaya mempopulerkan situs secara gratis dengan menggunakan teknik-teknik khusus untuk mengoptimalkan performa situs di halaman hasil pencarian search engine populer. Optimasi Search Engine seharusnya terdiri dari dua metode [11], yaitu :

1. Optimasi search engine Onpage adalah hal-hal yang dapat diubah pada halaman web, yaitu :
a. Title tags
b. Header tags
c. Huruf yang ditebalkan (bold), dimiringkan, digaris bawahi.
d. Alt image tags 
e. Meta Tags (keywords, description), dsb.

2. Optimasi search engine Offpage adalah optimization dari website-website yang berhubungan (memberi link) ke website anda. Misalnya:

a. Penggunaan 'Anchor text' pada link

b. Judul dari halaman dimana link ke website anda berada

c. 'Page rank' dari halaman dimana link ke website anda berada

d. "Tema" dari website yang link ke website anda.

Faktor-faktor lain yang mempengaruhi SEO [11], yaitu :

1. Memelihara layout situs yang baik

2. Kepuasan Pelanggan

3. Marketing/Pemasaran lewat Kesan/komentar

4. Kemudahan Akses

SEO Onpage yaitu melakukan optimasi dalam web dengan cara memodifikasi setingan bagian tertentu dalam web yang nantinya akan mempengaruhi penilaian website di search engine. Setingan tersebut bisa seperti menentukan title tag, meta keyword, meta description, membuat artikel yang berkualitas.

\section{Metode Penelitian}

Metode pengembangan sistem yang digunakan adalah metode sequential linier (waterfall). Penjelasan tahapan yang dilakukan dalam penelitian ini adalah sebagai berikut :

a. Analysis

Padatahap ini dilakukan analisis yang diperlukan dalam pelaksanaan pembuatan aplikasi plugin SEO untuk wordpress.

b. Design

Tahap penerjemahan dari data yang dianalisis kedalam bentuk yang mudah dimengerti oleh user, diantaranya pembuatan aplikasi SEO, dan membangun website yang mengandung SEO.

c. Coding

Rancangan sistem yang telah dibuatakan diimplementasikan kedalam bentuk coding program dengan menggunakan bahasa pemrograman PHP.

d. Testing

Tahap ini akan dilakukan uji coba serta evaluasi sistem yang akan dilakukan melalui server local. Bila sistem sudah berjalan dengan baik barulah diimplementasikan ke hosting website.

e. Maintenance

Tahap ini akan dilakukan perbaikan-perbaikan apabila sistem belum berjalan dengan baik atau terjadi kesalahan pada kondisi tertentu.

\section{Hasil dan Pembahasan}

\subsection{Analisis Sistem}

Sebelum memulai pembuatan sistem terlebih dahulu dilakukan analisa terhadap sistem yang akan dibuat, apa saja hal-hal yang harus di lakukan dalam merancang sistem SEO. Hal ini bertujuan agar dapat menentukan apa saja yang perlu dilakukan agar dapat memecahkan permasalahan-permasalahan yang ada.

Banyak faktor yang menyebabkan website tidak mendapatkan peringkat di search engine, kali ini penulis merangkum hal-hal penting yang seharusnya dilakukan oleh pemilik website, yaitu :

a. Pemilik website harus melakukan optimasi on page seperti melakukan setingan home page title, meta description, dan meta keyword. Melakukan penyetingan ini akan membuat website lebih terstruktur dan mudah diterjemahkan oleh google.

b. Melakukan optimasi terhadap artikel juga merupakan suatu keharusan, melakukan optimasi halaman artikel hampir sama dengan optimasi halaman home page. Optimasi yang dilakukan adalah title, description, dan keyword.

c. Agar dapat meraih peringkat terbaik di mesin pencarian maka sebaiknya melakukan riset keyword yang benar agar sesuai dengan apa yang biasa orang ketikkan di mesin pencarian.

d. Untuk menang dipersaingan yang ketat maka sebaiknya melakukan optimasi off page.

Point-point diatas adalah permasalahan yang akan diselesaikan dalam penelitian ini. Melalui sistem yang akan dibuat ini maka akan sangat mempermudah pemilik website memahami dan mempermudah dalam proses SEO.

\subsection{Solusi Analisis}


1. Algoritma Google

Google bukanlah satu-satunya website search engine yang ada di dunia ini. Persaingan website search engine juga begitu ketat seperti search engine yahoo, yandex dan bing. Maka dari itu google selalu melakukan update algoritmanya untuk bersaing menjadi lebih baik, tujuan lainnya adalah kepuasan pencari informasi. Google selalu melakukan update algoritmanya agar informasi-informasi yang dicari lebih relevan dan sesuai dengan kata kunci yang di ketikkan.

Dalam sistem search engine ada algoritma yang ditanamkan untuk mengolah dan menganalisis data dari setiap halaman website seperti nama domain, title, keyword, dan konten. Melalui proses inilah google menentukan peringkat website pada halaman search engine.

Dulu webmaster kebanyakan beranggapan untuk menang di halaman pertama google mereka harus melakukan teknik-teknik SEO kuno yang dibilang SEO friendly, hal ini berdampak buruk kepada pencari informasi seringkali kata kunci yang di ketikkan melenceng dengan isi yang diinginkan. Sehingga hal inilah yang membuat google merubah algoritmanya menjadi human friendly yang bertujuan agar informasi yang dicari lebih relevan dengan apa yang seharusnya dicari.

Pada era ini google menentukan peringkat pencarian dengan berdasarkan perilaku manusia. Google menerjemah perilaku manusia menjadi data yang nantikan akan digunakan untuk menentukan peringkat di mesin pencari. Misalnya artikel yang berkualitas dibaca dalam waktu yang lama dan direkomendasikan oleh pembaca.

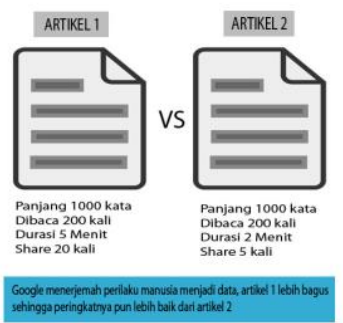

Gambar 1. Algoritma Google

Sebelum membahas tentang tahapan solusi optimasi website, peneliti ingin menampilkan skema tahapan yang perlu dipahami pemilik website sebelum melakukan optimasi.

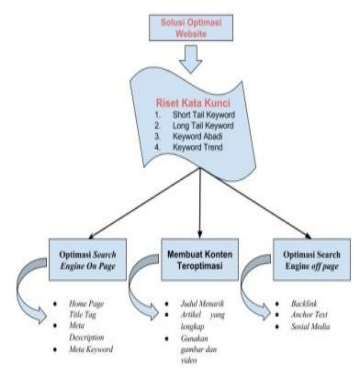

2. Riset Kata Kunci

Gambar 2. Solusi Optimasi Website

Riset kata kunci atau keyword yang tepat merupakan suatu hal yang paling terpenting saat optimasi website. Pemilihan kata kunci yang salah dapat menyebabkan website sepi pengunjung. Maka kesuksesan website yang utama ada pada proses riset kata kunci.

Sebelum melakukan riset kata kunci yang tepat sebaiknya terlebih dahulu mengerti berbagai jenis kata kunci yang ada:

a. Short tail keyword

Short tail keyword adalah kata kunci yang merupakan kumpulan dari dua atau tiga kata saja. Contohnya adalah belajar sablon, alat sablon, film korea, dan belajar bahasa korea. Jenis keyword ini memiliki tingkat persaingan yang sangat ketat. Untuk memenangkan persaingan di keyword ini perlu waktu yang lama dan juga memerlukan optimasi SEO yang sangat baik.

b. Long tail keyword

Long tail keyword adalah kata kunci yang memiliki kata yang panjang melebihi short tail keyword. Jenis kata kunci ini juga bisa dibilang kata kunci turunan dari kata kunci utama atau short tail keyword. Contohnya 
adalah belajar sablon untuk pemula, alat sablon murah di pekanbaru, film korea terbaik tahun 2016, dan belajar bahasa korea sehari-hari.

Untuk website yang masih baru long tail keyword menjadi pilihan yang tepat untuk mendatangkan pengunjung dari search engine. Jenis keyword ini memiliki tingkat persaingan yang sedang sehingga untuk website yang masih baru dibuat bisa saja mendapatkan peringkat terbaik di search engine.

c. Keyword abadi

Keyword abadi adalah kata kunci yang tidak termakan usia, dari zaman ke zaman orang selalu mengetikkan kata kunci ini di search engine. Contohnya adalah cara belajar sablon manual, review drama korea

Kata kunci ini merupakan kata kunci yang tidak termakan usia setiap waktu ke waktu kata kunci ini pasti akan selalu di ketikkan oleh seseorang yang ingin mencari informasi yang mereka inginkan.

d. Keyword musiman atau keyword trend

Keyword musiman adalah kata kunci yang sifatnya sementara tidak selalu dicari oleh para pencari informasi. Kata kunci ini biasanya sesuatu yang sifatnya populer atau informasi yang sedang trend. Contohnya adalah hasil pertandingan motor GP, hasil pertandingan real madrid vs Barcelona.

Kata kunci ini biasanya hanya akan mendatangkan pengunjung yang banyak saat lagi trend paling bertahan 2 sampai 3 hari. Setelah mengerti jenis-jenis keyword diatas selanjutnya barulah saatnya memulai riset kata kunci yang tepat. Untuk melakukan riset kata kunci bisa menggunakan tool google yang bernama Google Adword Keyword Planner.

Ada juga beberapa aplikasi lainnya yang bisa dipakai seperti Ubersuggest dan keywordtool. Berikut ini adalah langkah-langkah riset kata kunci yang baik:

1. Mencari kata kunci utama

Sebelum melakukan riset kata kunci sebaiknya memilih topik utama website yang dibuat dan penentuan topik website ini berhubungan dengan kata kunci utama sebuah website. Setelah menemukan keyword utama selanjutnya barulah menentukan keyword-keyword lainnya atau bisa disebut keyword turunan dari keyword utama. Contoh kata kunci utama untuk website dengan topik sablon: sablon, kaos, print digital, konveksi, drama korea.

2. Mencari keyword turunan dari keyword utama

Setelah menentukan keyword utama selanjutnya mencari turunan dari keyword tersebut. Tool yang digunakan untuk mencari kata kunci turunan adalah ubersuggest.io.

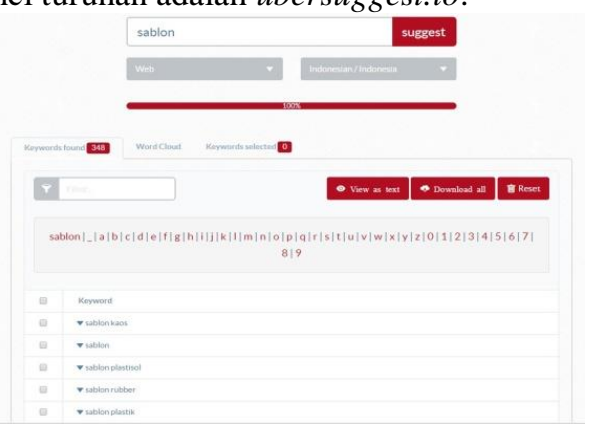

Gambar 3. Riset Kata Kunci Ubersuggest.io

Ketikkan keyword utama yang sekiranya berhubungan dengan topik website dan selanjutnya akan mendapatkan keyword turunan yang disarankan oleh ubersuggest.io.

3. Menganalisa keyword

Setelah mendapatkan keyword turunan selanjutnya adalah menganalisa keyword tersebut di search engine yang bertujuan agar mengetahui tingkat pencarian keyword tersebut pada search engine. Aplikasi yang digunakan untuk menganalisa keyword ini adalah Google AdWords Keyword Planner yang disediakan gratis oleh google. 


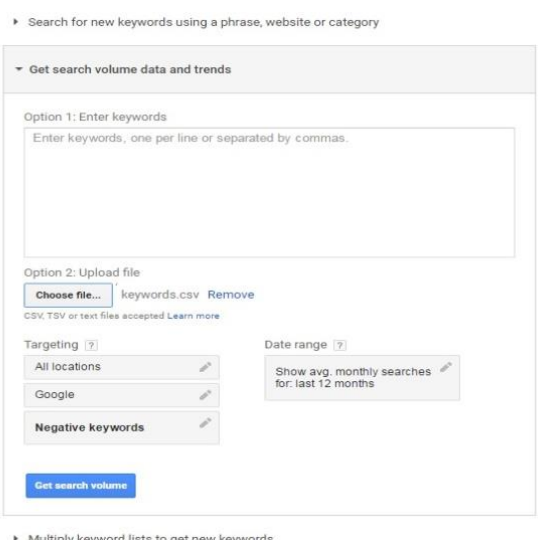

\section{Gambar 4. Riset Kata Kunci Google Keyword Planner}

Pilih menu Get search volume data and trends selanjutnya upload file keyword turunan yang sudah di riset dari ubersuggest.io. Setelah itu klik button Get search volume maka akan diarahkan kehalaman analisis keyword search engine google.

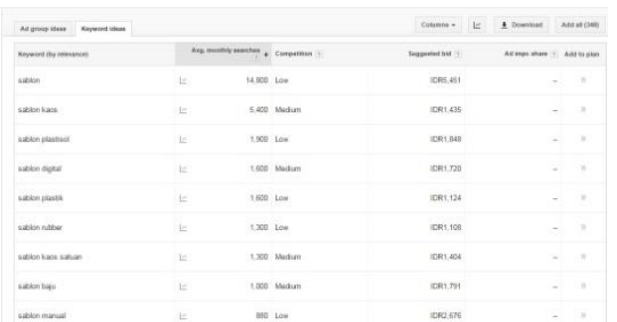

Gambar 5. Hasil Riset Kata Kunci

Dari gambar diatas bisa memberikan informasi berapa banyak keyword yang ditargetkan dicari atau diketikkan pada search engine. Dari data tersebut kata kunci "sablon kaos" dicari sekitar 5.400 orang setiap bulannya.

4. Analisis tingkat persaingan

Langkah terakhir yang perlu dilakukan adalah melihat tingkat persaingan kata kunci di search engine. Aplikasi yang diperlukan untuk menganalisa ini adalah dengan extensi browser, SEOQuake berguna untuk melihat alexa rank, pagerank, umur domain dan extensi lainnya adalah MozBar tool ini berguna untuk melihat backlink, page authority (PA) dan domain authority(DA).

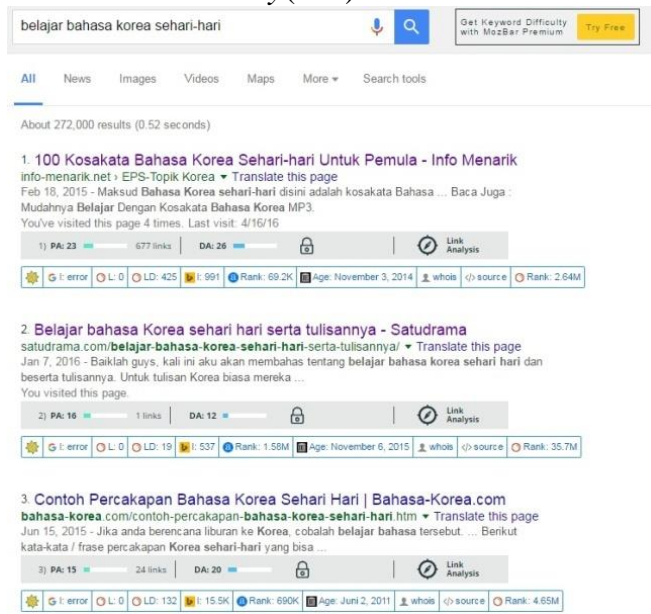

Gambar 6. Analisis Tingkat Persaingan Keyword

Dari gambar diatas dapat disimpulkan tingkat persaingan kata kunci yang ditargetkan. Tingkat persaingan itu dapat disimpulkan sebagai berikut:

a. Tingkat persaingan dengan pencarian 272.000

b. Page Authority dan Domain Authority dibawah 50 melambangkan tingkat persaingan tidak terlalu sulit. 
Agar keyword yang ditarget bisa mendapatkan peringkat terbaik pada search engine maka yang harus dihindari adalah:

a. Hindari kata kunci yang memiliki pencarian di atas satu juta.

b. Bila website terbilang masih baru sebaiknya hindari pemilihan kata kunci yang telah dikuasi oleh website otoritas seperti wikipedia.

c. Jangan memilih kata kunci yang memiliki Page Authority dan Domain Authority diatas 50.

4.3 Optimasi Search Engine On Page

Tahap awal yang perlu dilakukan oleh pemilik website adalah dengan melakukan optimasi SEO on page. Melakukan optimasi on page adalah upaya mengoptimalkan struktur website agar tertata dengan baik yang nantinya akan mempermudah proses pembacaan oleh google. Berikut ini adalah langkah melakukan optimasi SEO on page:

a. Home Page Title Tag

Home Page Title tag adalah kata yang pertama kali dibaca oleh robot mesin pencari, title tag juga menjadi kata kunci utama dan merupakan judul utama dalam sebuah website. Contoh home page title tag: Belajar sablon manual.

b. Meta Description

Meta description adalah deskripsi yang menjelaskan dari title tag yang telah dibuat tadi. Melakukan optimasi meta description sangat disukai oleh google, namun selain itu melakukan optimasi meta description juga dapat menarik perhatian pencari informasi untuk mengunjungi website. Contoh meta description: "Kedaisablon.com adalah website yang berbagi tentang seputar informasi dunia sablon, tips belajar sablon, alat-alat sablon, dan lainnya".

c. Meta Keyword

Meta Keyword adalah kata kunci utama yang melambangkan topik website. Melakukan optimasi meta keyword ini juga mampu mempermudah search engine menerjemah kata kunci website yang akan berdampak pada peringkat di SERP. Contoh meta keyword: "Belajar sablon manual, alat-alat sablon".

d. Melakukan Optimasi $U R L$

Optimasi $U R L$ atau optimasi link tidak kalah pentingnya dalam proses meraih peringkat terbaik di search engine. Search engine akan lebih mengerti maksud dari kata kunci yang ditargetkan apabila pemilik website melakukan optimasi $U R L$ yang baik. URL website sangat berperan penting dalam proses Optimasi website karena url menguatkan topik dari website itu sendiri. Sebaiknya url website ini mengandung kata kunci yang ditargetkan. Contoh url yang baik: "http://kedaisablon.com/belajar-sablon-untuk-pemula".

Setingan ini dapat kita lakukan di halaman settings pada wordpress dan pilih menu permalinks, pilih opsi post name.
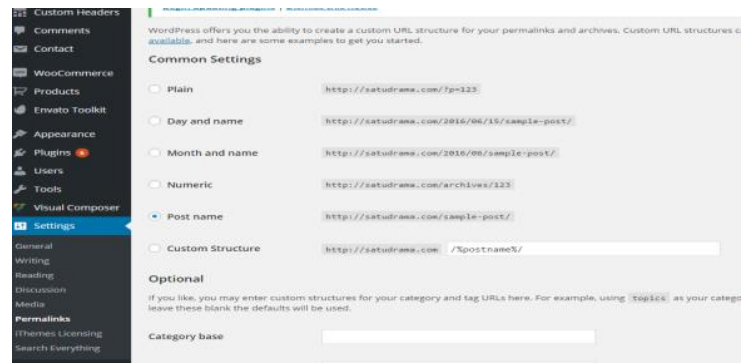

Gambar 7. Setting Permalinks

\subsection{Membuat Konten Teroptimasi}

Semakin baik artikel dan memberi manfaat yang baik pula maka akan berpeluang besar muncul di halaman utama search engine. Berikut ini unsur penting yang perlu ada pada artikel yang baik dan berkualitas.

a. $\quad$ Buat judul yang menarik

Judul merupakan tombak utama bagi website karena judul yang baik mampu menarik perhatian pencari informasi untuk mengklik website di mesin pencari. 


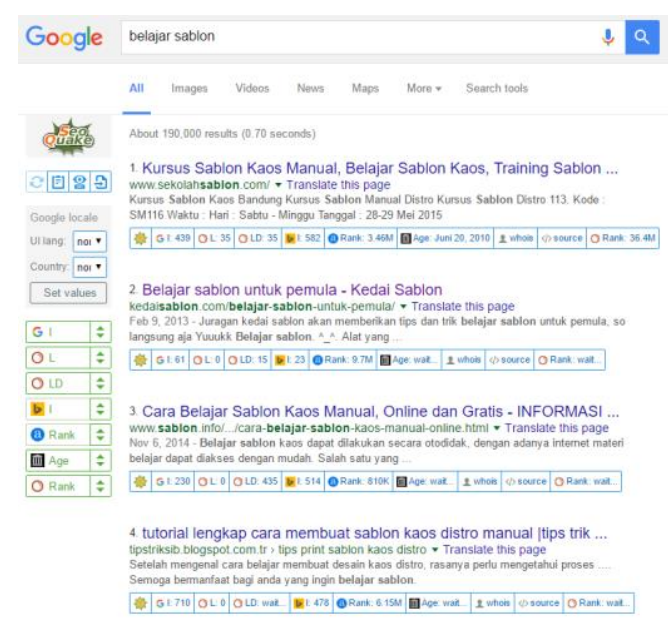

Gambar 8. Contoh Judul yang Menarik

b. Menulis artikel yang lengkap

Menulis artikel yang lengkap merupakan suatu hal yang wajib dilakukan oleh pemilik website. Pencari informasi tentunya pasti sangat terbantu apabila suatu artikel mampu menjelaskan dengan baik dan lengkap apa yang mereka cari, sehingga tidak perlu mencari informasi ke website lainnya. Artikel yang berkualitas biasanya memiliki minimal 1000 kata, artikel yang panjang tentunya akan membuat artikel tersebut menjadi berkualitas dan memberi manfaat yang baik. Namun belum tentu juga artikel yang panjang itu berkualitas.

c. Gunakan gambar untuk menjelaskan isi artikel

Artikel yang baik seharusnya memiliki perpaduan kata-kata, gambar, dan video yang mampu menjelaskan secara lengkap apa yang di bahas. Adanya gambar yang mampu menjelaskan maksud dari topik pembahasan akan membuat pencari informasi merasa terbantu dan akan betah lebih lama membaca artikel tersebut. Agar mendapatkan peringkat di search engine lebih baik lagi melakukan optimasi pada gambar dengan cara simpan gambar yang akan di unduh sesuai dengan kata kunci yang ditargetkan.

d. Gunakan video jika diperlukan

Adanya video dalam sebuah artikel akan menambah kualitas artikel tersebut. Video yang tepat akan memberikan informasi yang lebih dan memberi kenyamanan bagi pengunjung yang membaca artikel tersebut.

\subsection{Optimasi Search Engine Off Page}

Optimasi SEO off page adalah upaya optimasi yang dilakukan dari luar website. Di tingkat pencarian kata kunci yang memiliki persaingan yang ketat tidak akan cukup hanya dengan melakukan optimasi SEO on page maka perlu dilakukan optimasi SEO off page agar mampu bersaing dengan website lainnya.

Google memiliki bot yang bekerja dengan cara berkunjung dari website ke website dari link yang tercantum dalam setiap halaman website. Google bot menggunakan link sebagai navigasinya, website yang memiliki link dari luar akan menjadi prioritas kunjungan dari googlebot. Website yang memiliki link dari luar yang banyak dan berkualitas maka semakin baik pula peringkat website tersebut di halaman search engine.

Hal yang perlu dilakukan oleh pemilik website adalah mencari link dari luar yang memiliki kualitas tinggi. Salah satu backlink atau link luar dari website yang baik adalah sosial media. Sosial media adalah salah satu cara yang paling mudah memperkenalkan website kepada orang banyak. Semakin populer website tersebut di sosial media maka akan berdampak besar untuk meraih peringkat di search engine. Maka website yang baik seharusnya melakukan promosi di sosial media.

SEO off page bisa dibilang permainan kepopuleran sebuah website. Google menggunakan beberapa faktor dalam menilai kepopuleran sebuah website.

1. Kualitas Backlink

Dalam penentuan backlink yang berkualitas google memiliki unsur penilaian yang begitu ketat. Tentunya backlink yang berkualitas akan berpengaruh besar pada peringkat search engine ketimbang backlink yang tidak berkualitas. Adapun unsur backlink yang berkualitas dapat disimpulkan sebagai berikut:

a. Reputasi dan keaktifan website yang memberi link ke website pemilik

b. Kesamaan bahasa dan topik pembahasan

c. Penempatan backlink dalam website 
2. Menggunakan anchor text dalam backlink

Anchor text adalah kata kunci yang di beri link. Google memberikan penilaian lebih apabila backlink yang dibuat dengan anchor text. Namun penggunakan anchor text yang berulang-ulang dalam satu artikel tidak akan memberikan dampak yang positif lagi. Jadi sebaiknya dalam satu artikel memiliki satu backlink anchor text.

3. Aktif di sosial media

Website yang populer di sosial media akan dinilai baik oleh search engine google. Apabila artikel yang dibuat direkomendasikan atau di share oleh pengunjung maka website tersebut akan mendapatkan penilaian yang baik oleh search engine google. Semakin tinggi keaktifan di sosial media maka semakin baik pula peringkat website di search engine.

\section{Kesimpulan}

Berdasarkan pembahasan dan uraian mengenai sistem SEO yang telah dibahas maka dapat disimpulkan:

1. Dengan melakukan Optimasi search engine yang telah penulis bahas maka hasilnya akan mampu membuat website meraih peringkat di search engine.

2. Menggunakan plugin wordpress yang telah penulis buat akan mempermudah pemilik website melakukan penyetingan optimasi.

3. Riset keyword yang baik sangat berperan penting dalam proses mendapatkan peringkat di google.

4. Artikel yang berkualitas akan membuat website mendapatkan peringkat terbaik di search engine.

5. Untuk menang di kata kunci yang persaingannya ketat maka diperlukan optimasi off page yang baik. Pencarian backlink yang berkualitas menjadi keharusan yang perlu dilakukan oleh pemilik website.

\section{Daftar Pustaka}

[1] R. Dewi, P. A. Janitra, P. A. Janitra, N. Aristi, and N. Aristi, "Pemanfaatan Internet Sebagai Sumber Informasi Kesehatan Bagi Masyarakat,” Media Karya Kesehat., vol. 1, no. 2, pp. 162-172, 2018.

[2] E. P. Setiawan and I. Ismurjanti, "Penggunaan Internet sebagai sumber informasi dalam penyusunan karya ilmiah Siswa SMA Negeri 8 Yogyakarta,” J. Kaji. Inf. dan Perpust., vol. 6, no. 2, pp. 169-182, 2018.

[3] Y. D. Pramudita, H. Huzaini, and F. Solihin, "Penerapan Metode Seo on Page Dan Off Page Pada Web Penjualan Online Untuk Meningkatkan Ranking Serp," Netw. Eng. Res. Oper., vol. 4, no. 2, pp. 125-133, 2019.

[4] S. Sukri and D. Arisandi, "Analisis Strategi Pemasaran Dengan Media Sosial Produk Kuliner Usaha Kecil dan Menengah di Pekanbaru," J. Buana Inform., vol. 8, no. 4, pp. 235-242, 2017.

[5] H. Artanto and F. Nurdiyansyah, "Penerapan SEO (Search Engine Optimization) Untuk Meningkatkan Penjualan Produk," JOINTECS (Journal Inf. Technol. Comput. Sci., vol. 2, no. 1, pp. 2-5, 2017.

[6] E. P. Utomo, "Melesatkan prestasi akademik dengan internet," Bandung: Yrama Widya, 2013.

[7] T. Graham, "Platforms and hyper-choice on the World Wide Web," Big Data Soc., vol. 5, no. 1, pp. 112, 2018.

[8] A. Budiman, A. Arifin, and F. Marlianto, "Pengembangan media pembelajaran berbasis e-learning pada SMK di Pontianak," J. Nas. Komputasi dan Teknol. Inf., vol. 2, no. 2, pp. 133-139, 2019.

[9] S. Rohayati, "PERANCANGAN WEBSITE UNIT KEGIATAN MAHASISWA AEROMODELLING DI NIVERSITAS SURYADARMA,” J. Chem. Inf. Model., vol. 53, no. 9, pp. 1689-1699, 2013.

[10] K. Purcell, J. Brenner, and L. Rainie, "Search engine use 2012. Pew Internet \& American Life Project," Pew Res. Center's Internet Am. Life Proj., 2012.

[11] A. Abdurrahman, "Analisis Pengaruh Kata Kunci Kompetitif Pada Search Engine Optimization (SEO) Terhadap Pemasaran Online Untuk Produk Notebook," J. Ilm. Inform. Komput., vol. 3, p. 19, 2014. 